\title{
Corrosion inhibitors for reinforced concrete structures: a study of binary mixtures
}

\author{
A. Brenna, F. Bolzoni,* MP. Pedeferri and M. Ormellese \\ Politecnico di Milano, Dipartimento di Chimica, Materiali e Ingegneria Chimica \\ “Giulio Natta”, Via Mancinelli 7, 20131 Milano, Italia \\ E-mail: fabio.bolzoni@polimi.it
}

\begin{abstract}
Corrosion inhibitors are used to prevent or delay corrosion of steel reinforcement in concrete. Available commercial products are of inorganic nature based on sodium nitrite (acknowledged to be the most effective product), or organic mixtures based on amines, alkanolamines, fatty acids and carboxylic substances. During the last 15 years in our laboratories an intense experimental research aimed at identifying new organic substances or mixtures thereof that might have greater inhibiting effectiveness on corrosion by chlorides. This paper present the results of electrochemical tests carried out in alkaline solution, in the presence of chlorides, that were conducted on binary mixtures made with three substances (nitrite, DMEA and benzoate). Electrochemical tests (namely potentiodynamic and potentiostatic polarisation) were carried out. Some of the mixtures exhibited a marked synergistic effect in the potentiodynamic polarisation tests, with a clear-cut increase in the pitting potential. In potentiostatic polarisation the effect on the critical chloride concentration for the initiation of localised corrosion were limited.
\end{abstract}

Keywords: rebar corrosion, chlorides, inhibitors, critical chloride content, mixtures, pitting potential, potentiostatic polarisation.

Received: January 18, 2017. Published: February 13, 2017.

doi: $\underline{10.17675 / 2305-6894-2017-6-1-5}$

\section{Introduction}

The main cause of decay of reinforced concrete structures is the corrosion of rebars (reinforcing steel): this phenomenon can be due to concrete carbonation or to the presence of chlorides, at the surface of rebars, in a concentration exceeding the critical threshold, typically ranging within the $0.4-1 \%$ interval $v s$. weight of cement [1]. The critical chloride content is strongly influenced by the electrochemical potential, as usefully described by the "Pedeferri Diagrams" for cathodic protection and prevention [2]. Prevention from corrosion is actualized during the design phase by crafting a concrete of suitable quality, with a low water/cement ratio, by performing a correct curing and casting, and by using an appropriate bar cover thickness. The European standards set out the threshold values of such a parameter in relation to environmental aggressiveness [3,4]. With regard to structures exposed to very corrosive environments, or for structures with a design life over 
50 years, it would be appropriate to resort to additional protective methods: blended cements, corrosion-resistant reinforcing steel, inhibitors of corrosion, concrete coatings and cathodic protection. Among these methods, inhibitors of corrosion offer a simple and lowcost solution compared to other techniques.

Inhibitors of corrosion may be used as a corrosion-prevention method, when added directly to fresh concrete, or as a restoration method for already corroded rebars, if added on the external surface of the concrete and left to migrate inside it $[5,6]$. On the market, both inorganic products (based on calcium nitrite) and organic formulations are available [5-7]. Inhibitors based on calcium nitrite are internationally regarded as the most effective against corrosion: their inhibiting mechanism is well known, and the dosage is indicated in relation to the content of chlorides in the concrete $[8,9]$. Organic commercial inhibitors, available since the $80 \mathrm{~s}$ of the previous century, are mixtures of amines, alkanolamines and carboxylate compounds. However, despite the fact that the active principles are known, their composition is not defined, and the dosage of inhibitor required to prevent corrosion in relation to the chloride content is not always provided. Literature data record an increase in the critical chloride content up to a maximum $1.5 \%$ compared to the weight of cement $[5,10-16]$.

The last years have witnessed a growing interest in the study of new compounds capable of preventing or delaying corrosion and facilitating comprehension of the inhibitory mechanism. Studies have been conducted on non-commercial inhibitors, both inorganic (zinc oxide, molybdates, borates, stannanes, phosphates) and organic compounds (benzoate and its derivatives, carboxylate substances, quaternary ammonium salts, citrate and amine-based substances) [5, 19-30].

This paper present the results of electrochemical tests (cyclic potentiodynamic polarization and potentiostatic polarisation) performed on binary mixtures made with 2 organic substances and nitrites with a view to identifying possible synergistic effects in the inhibition of corrosion by chlorides. The organic substances have been selected during a prior research phase, in the course of which 100 organic substances containing amino or carboxylic groups have been tested [31-34].

\section{Experimental Methodology}

The potentiodynamic polarization tests have been conducted with the aid of an EG\&G Princeton Applied Research potentiostat, in an electrochemical cell, by utilizing as working electrode a corrugated carbon steel rebar with improved adhesion (nominal diameter $10 \mathrm{~mm}$, length $40 \mathrm{~mm}$ ), as reference a saturated calomel electrode (SCE, +244 mV compared to the standard hydrogen electrode), and as counter electrode a platinum electrode.

The two ends of the working sample have been shielded with a polymer coating (selfamalgamating sheath) in order to isolate from the solution the transversal surfaces and obtain an exposed side surface of $10 \mathrm{~cm}^{2}$. The specimen is sandblasted in order to remove 
the passivation film from the surface left uncovered by the sheath. The specimen is then assembled on a sample-holding bar. Figure 1 illustrates the scheme of assembly.

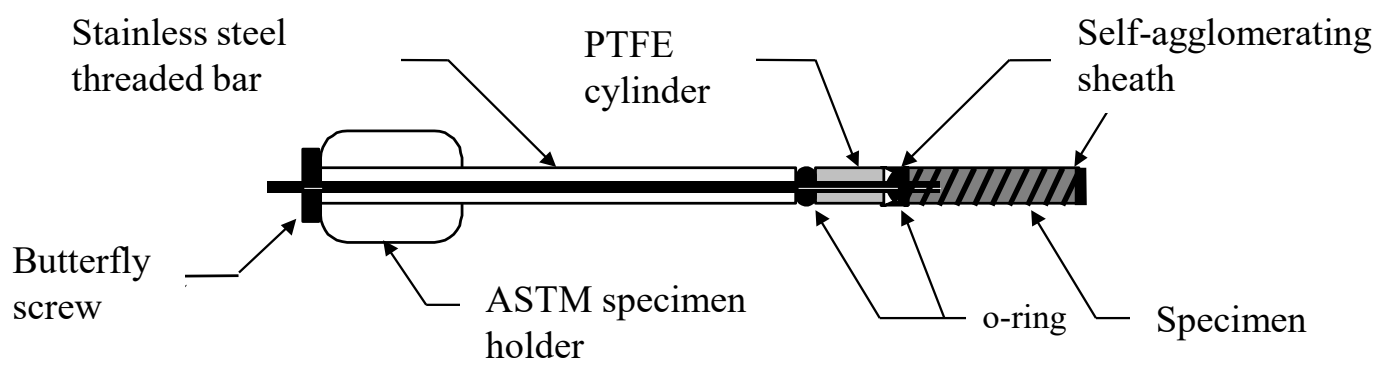

Figure 1. Assembly of the test piece on the sample-holder.

The cyclical potentiodynamic test has been conducted in accordance with ASTM G61 [35] by increasing the working electrode potential through a $1 \mathrm{~V} / \mathrm{h}$ scanning speed, starting from $-1.2 \mathrm{~V} \mathrm{SCE}$ all the way up to a corresponding potential at a current density of $10 \mathrm{~A} / \mathrm{m}^{2}$; thereafter, the potential has been decreased down to $-1.2 \mathrm{~V} \mathrm{SCE}$. The test began after immersing the sample in the solution. The measurements (circulating current density and difference of potential between metal and reference electrode) have been obtained through PC 352 SoftcorrIII software. All the tests have been performed in alkaline solution $(\mathrm{pH} 13)$, simulating the solution of pores in concrete [1], obtained by adding distilled water $2 \mathrm{~g} / \mathrm{L}$ of calcium hydroxide and $\mathrm{NaOH} 0.1 \mathrm{~mol} / \mathrm{L}$.

Reference tests were conducted in the absence of inhibitors and in the presence of pure substances with $0.1 \mathrm{~mol} / \mathrm{L}$ content. The pure substances examined in this paper are the following: one amine, dimethylethanolamine (DMEA), one carboxylate (benzoate) and one inorganic (nitrite). These substances have been selected on the basis of the results of the test carried out in solution on single substance; moreover, they form part of the current commercial corrosion inhibitors [5].

Table 1. Analysed substances.

\begin{tabular}{lll}
\hline Inorganic & Nitrite & $\mathrm{NaNO}_{2}$ \\
\hline Amines & Dimethylethanolamine (DMEA) & $\left(\mathrm{CH}_{3}\right)_{2} \mathrm{~N}\left(\mathrm{OH} \mathrm{CH} \mathrm{CH}_{2}\right)-$ \\
\hline Carboxylates & Sodium benzoate & $\mathrm{C}_{6} \mathrm{H}_{5}-\mathrm{COOH}$ \\
\hline
\end{tabular}

The tests with binary mixture were carried out in compliance with the following molar ratios between the two substances (A and $\mathrm{B}$ ), by maintaining the total concentration of inhibiting substances at $0.1 \mathrm{~mol} / \mathrm{L}$ :

- $0.09 \mathrm{~mol} / \mathrm{L}$ of $\mathrm{A}+0.01 \mathrm{~mol} / \mathrm{L}$ of $\mathrm{B}$

- $0.05 \mathrm{~mol} / \mathrm{L}$ of $\mathrm{A}+0.05 \mathrm{~mol} / \mathrm{L}$ of $\mathrm{B}$

- $0.01 \mathrm{~mol} / \mathrm{L}$ of $\mathrm{A}+0.09 \mathrm{~mol} / \mathrm{L}$ of $\mathrm{B}$ 
In some instances, a study was also conducted on the mixture of $0.07 \mathrm{~mol} / \mathrm{L}$ of $\mathrm{A}$ (or B) and $0.03 \mathrm{~mol} / \mathrm{L}$ of $\mathrm{B}$ (or A)

After adding the substances, the $\mathrm{pH}$ of the solution was raised to 13 through the addition of $\mathrm{NaOH}$. Thereafter, chlorides with a $0.1 \mathrm{~mol} / \mathrm{L}$ content were added.

Potentiostatic polarization tests. Some of the mixture tested in previous tests have been also tested in potentiostatic polarization: in these tests, 13 carbon steel specimens (the same in Figure 1) have been placed in a $3 \mathrm{~L}$ cylindrical cell $(20 \mathrm{~cm}$ in diameter). Specimens have been polarized at $0 \mathrm{mV}$ SCE, using an activated titanium net-wire as counter-electrode placed in the bottom of the cell. The polarisation potential simulates the corrosion behaviour of carbon steel rebar in pristine concrete exposed to atmosphere. The current flowing in each sample has been monitored through a series of shunts. The solution was initially chlorides free: as soon as current density reached values typical of passive conditions (passive current density lower than $1 \mathrm{~mA} / \mathrm{m}^{2}$ ), chlorides were periodically added every $80-90 \mathrm{~h}$ to the solution $(0.05,0.1,0.2 \mathrm{up}$ to $0.8 \mathrm{~mol} / \mathrm{L})$. Corrosion occurrence was revealed by increase in the current and confirmed by visual inspection.

\section{Results and Discussion}

The cyclical potentiodynamic tests allowed us to identify the value of the pitting potential (potential at which a clear-cut increase in the anode current was recorded) and the repassivation potential (potential at which the return curve intersects the portion of passivity).

The pitting potential of tests carried out in alkaline solution without inhibitor with chloride content of $0.1 \mathrm{~mol} / \mathrm{L}$ amounts to $-200 \mathrm{mV} \mathrm{SCE}$. Among the pure substances, nitrite exhibits a considerable increase in the pitting potential, reaching up values in excess of even $+500 \mathrm{mV}$ SCE. In all the other instances, the pitting potential values range between +50 and $-100 \mathrm{mV}$ SCE. The worst behaviour was measured with DMEA [32].

All the pure substances and mixtures examined, save for nitrite, evinced no significant increases of the repassivation potential compared to tests in the absence of inhibitor: the values range between -400 and $-450 \mathrm{mV} \mathrm{SCE} \mathrm{[32].} \mathrm{In} \mathrm{the} \mathrm{following} \mathrm{this} \mathrm{parameter} \mathrm{will}$ not be discussed and reference will be made to pitting potential only.

\subsection{Potentiodynamic polarisation tests}

The effectiveness of binary mixtures in inhibiting corrosion by chlorides on rebars in reinforced concrete has been assessed by comparing the pitting potential values with the results achieved in the reference solution in the absence of inhibitor (alkaline solution of saturated $\mathrm{Ca}(\mathrm{OH})_{2}$ with $0.01 \mathrm{~mol} / \mathrm{L} \mathrm{NaOH}$ and the addition of $0.1 \mathrm{~mol} / \mathrm{L}$ chlorides) as well as through the tests performed in the presence of pure substances.

The pitting potential data of bi-component mixtures (Table 2) have been compared with the potentials that would prevail if the inhibitory effects of the two components were linearly combined. In the absence of synergistic or pejorative effects, in fact, we may assume a theoretical pitting potential of every mixture obtained as average of the pitting 
potentials of the two constituents weighted in accordance with their respective concentration:

$$
E_{\mathrm{m}}^{*}=X_{\mathrm{A}} \times E_{\mathrm{A}}+X_{\mathrm{B}} \times E_{\mathrm{B}},
$$

where $E_{\mathrm{m}}^{*}$ denotes the pitting potential of the theoretical A $+\mathrm{B}$ mixture, $X_{\mathrm{A}} \& X_{\mathrm{B}}$ represent the molar fraction of $\mathrm{A}$ and $\mathrm{B}$ in the mixture, and $E_{\mathrm{A}} \& E_{\mathrm{B}}$ are the pitting potentials of pure A or B components, with a $0.1 \mathrm{~mol} / \mathrm{L}$ content.

Table 2 - Pitting potential (mV SCE) of mixtures.

\begin{tabular}{cccccccc}
\hline \multirow{2}{*}{ Component A } & \multicolumn{6}{c}{ dosage (\%-molar) } & \multirow{2}{*}{ Component B } \\
\cline { 2 - 7 } & $\mathbf{1 0 0 - \mathbf { 0 }}$ & $\mathbf{9 0 - 1 0}$ & $\mathbf{5 0 - 5 0}$ & $\mathbf{3 0 - 7 0}$ & $\mathbf{1 0 - 9 0}$ & $\mathbf{0}-\mathbf{1 0 0}$ & \\
\hline \multirow{2}{*}{ mol/L Component A } & $\mathbf{0 . 1}$ & $\mathbf{0 . 0 9}$ & $\mathbf{0 . 0 5}$ & $\mathbf{0 . 0 3}$ & $\mathbf{0 . 0 1}$ & $\mathbf{0}$ & \\
\hline \multirow{2}{*}{ Nitrite } & 500 & 435 & 350 & 570 & 270 & 25 & Benzoate \\
\cline { 2 - 7 } & & 455 & 150 & & -135 & -145 & DMEA \\
\hline Benzoate & 25 & 100 & 30 & & 70 & -145 & DMEA \\
\hline
\end{tabular}

The results have been represented in Figures 2-4; we may identify the following characteristic values (all of them referred to the saturated calomel electrode or SCE):

- $E_{\mathrm{r}}=$ pitting potential of the reference solution without inhibitors

- $E_{\mathrm{A}}, E_{\mathrm{B}}=$ pitting potential of the solution with single inhibitor $\mathrm{A}$, or $\mathrm{B}$

- $E_{\mathrm{m}}=$ experimental pitting potentials of the mixture

- $E_{\mathrm{m}}^{*}=$ pitting potential of the mixture expected in the absence of synergistic effects

The inhibitory effect is accordingly assessed as follows:

- increase in the pitting potential of the mixture compared to a linear sum of the effects of single constituents $\left(\Delta E_{\mathrm{m}-\mathrm{m}^{*}}\right)$

$\circ \Delta E_{\mathrm{m}-\mathrm{m}^{*}}>0$ mixture with synergistic effect

$\circ \Delta E_{\mathrm{m}-\mathrm{m}^{*}}<0 \quad$ mixture with pejorative effect

- increase in the pitting potential of the mixture compared to the reference solution $\left(\Delta E_{\mathrm{m}-\mathrm{r}}\right)$

$\circ \Delta E_{\mathrm{m}-\mathrm{r}}>300 \mathrm{mV} \quad$ significant inhibitory effect

The nitrite-benzoate mixture exhibits synergistic effects, reaching the maximum values for mixtures with approximately $30 \%$ of nitrite $\left(\Delta E_{\mathrm{m}-\mathrm{m}^{*}} \approx 450 \mathrm{mV}\right)$, see Figure 2 . The pitting potential approximates $600 \mathrm{mV} \mathrm{SCE}$, with an increase of $800 \mathrm{mV}$ over the value in the absence of inhibitor. At low nitrite concentrations $(<50 \%)$ there is a clear 
synergistic effect, whereas, with higher values, the components tend to be substantially independent. The synergistic behaviour between nitrite and benzoate was already observed by other authors [22].

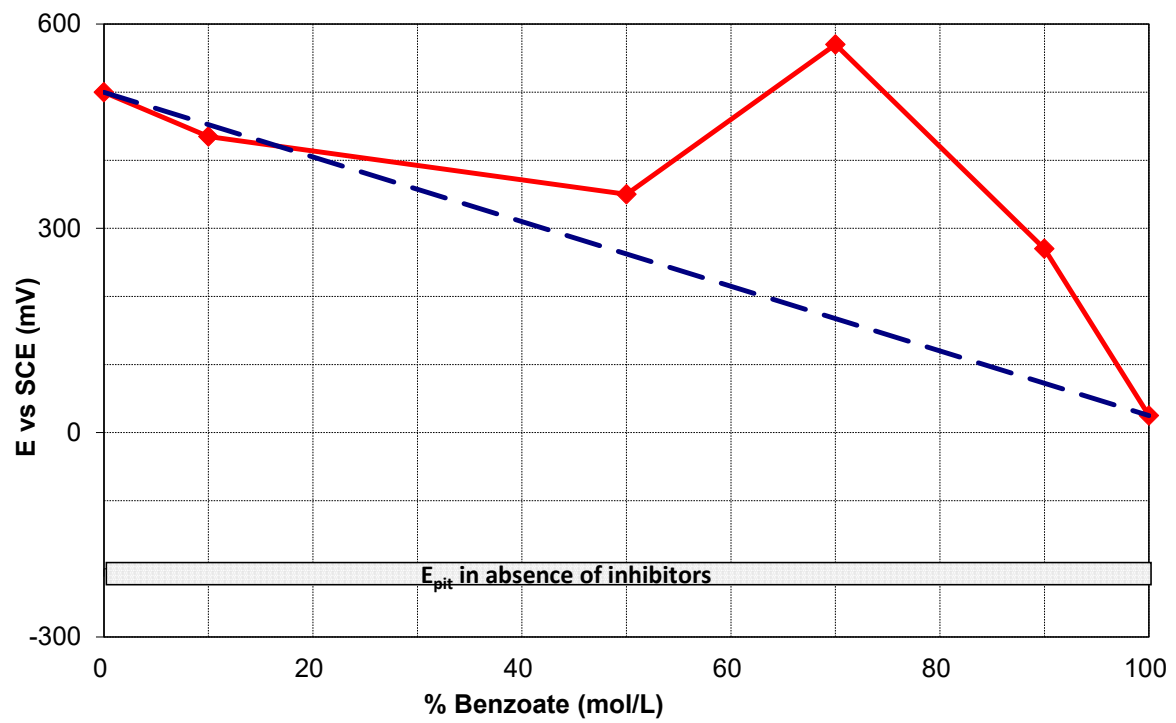

Figure 2. Effect on $E_{\text {pit }}$ of the nitrite-benzoate mixture.

The trend of the results for the nitrite-DMEA mixtures are shown in Figure 3 it is evident the lack of a synergistic effect between the two substances, the trend of the $E_{\text {pit }}$ is practically linear with the composition. The results are affected by the poor performance of DMEA, already highlighted by other authors and the same research group [5, 32, 34].

In the case of benzoate and DMEA mixtures, the synergistic effect occur for all the composition range, although the value of the pitting potential remain well lower (about $300 \mathrm{mV}$ ) than in the case of benzoate-nitrite mixtures.

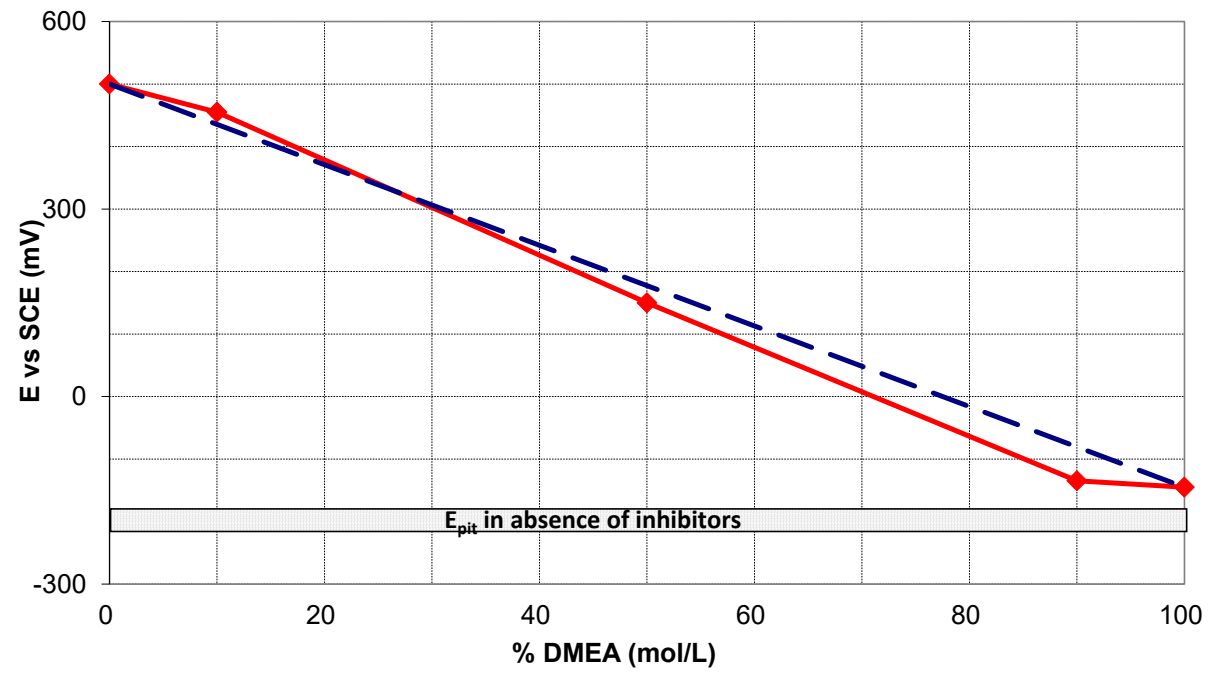

Figure 3. Effect on $E_{\text {pit }}$ of the nitrite-DMEA mixture. 


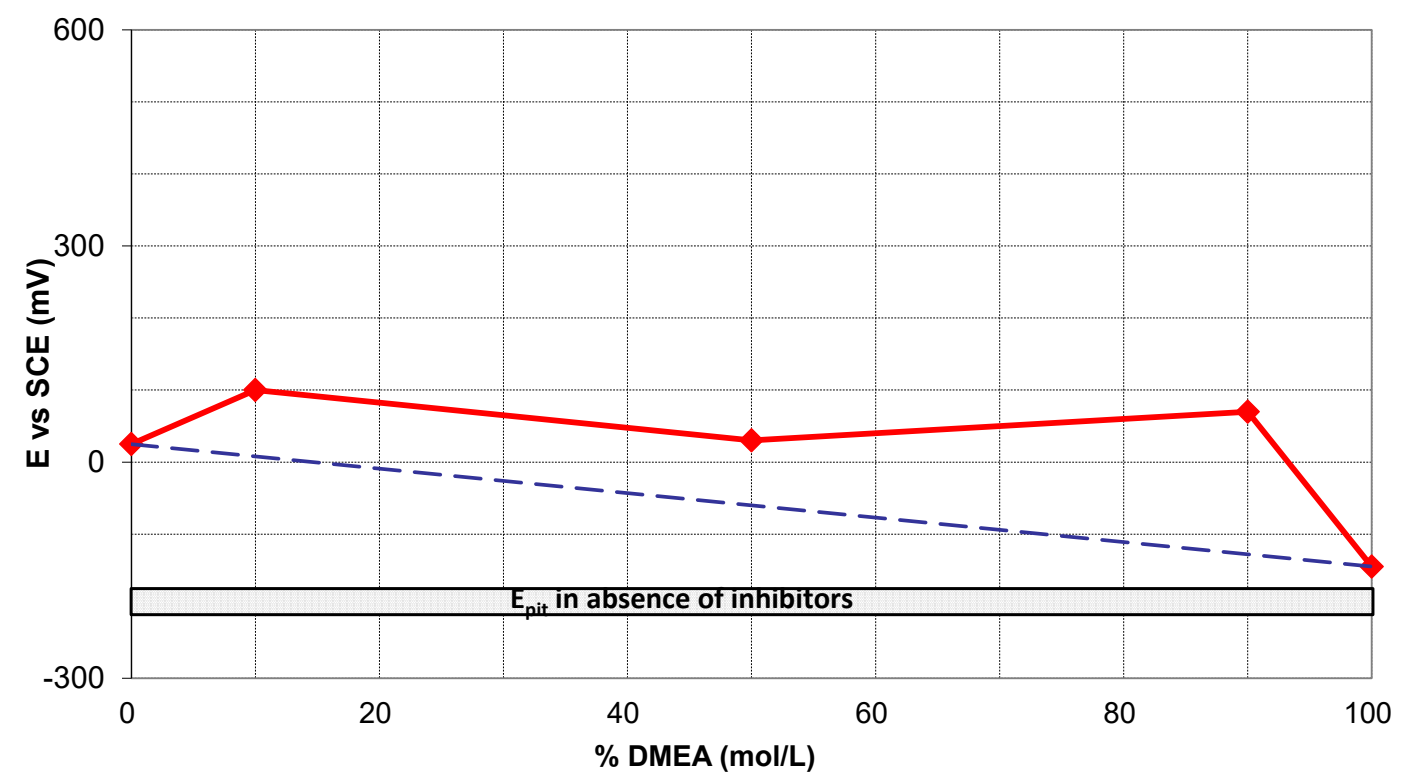

Figure 4. Effect on $E_{\mathrm{pit}}$ of the benzoate-DMEA mixture.

\subsection{Potentiostatic polarisation tests}

Due to poor performance of the mixture benzoate-DMEA, only nitrite-benzoate and nitrite-DMEA mixtures were tested.

The results of the potentiostatic polarisation tests are shown in the Figures 5 and 6: all tested mixtures were able to improve the critical chloride content found in solution without addition of corrosion inhibitors $(0.05 \mathrm{M})$.

While for single substance the performance is much better for benzoate than for DMEA, in the mixtures of both with nitrite and the same molar concentration $(0.05 \mathrm{~mol} / \mathrm{L}$ for each), the performance improves more for the mixture nitrite-DMEA, that in any case is not able to provide a performance similar to the nitrite alone with $0.1 \mathrm{M}$.

Comparing the behaviour of two mixtures between nitrite and benzoate, the best performance is observed for the $0.07 \mathrm{M}$ benzoate $-0.03 \mathrm{M}$ nitrite (Figure 6), in agreement with the results of the potentiodynamic polarisation tests (Figure 2). In any case, it seems that the synergistic effect found in potentiodynamic polarisation tests is not confirmed in potentiostatic polarisation.

The same approach used to highlight the efficiency of the mixtures in increasing the pitting potential was used to elaborate the data of critical chloride concentration. In this case mean value with the range between the minimum and the maximum are shown. No significant synergistic effect is evident, in the case of nitrite-benzoate mixtures there is even a pejorative effect for low benzoate concentration, while additive effect is prevailing at higher concentration of benzoate (see Figure 7). The behaviour of the nitrite-DMEA mixtures is additive, and this result is in agreement with those of potentiodynamic polarisation tests (compare Figure 8 with Figure 4). 


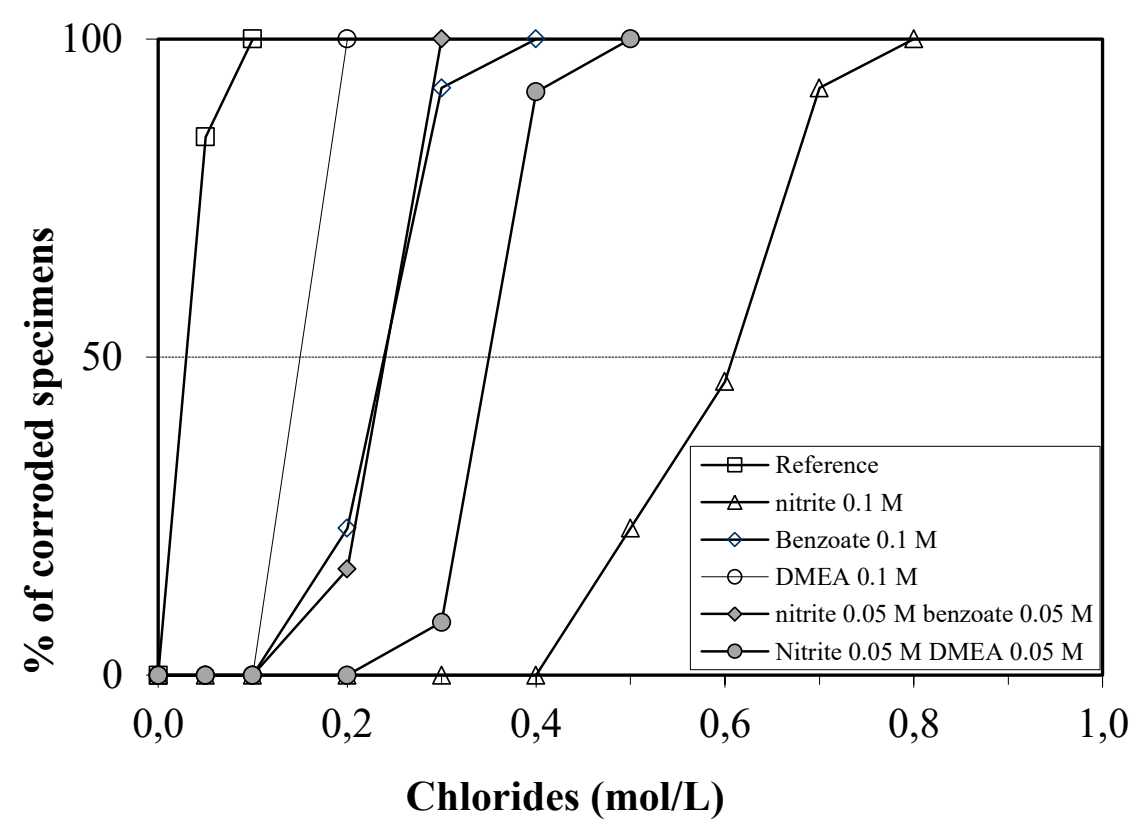

Figure 5. Results of the potentiostatic polarisation tests: comparison of nitrite-benzoate and nitrite-DMEA mixtures.

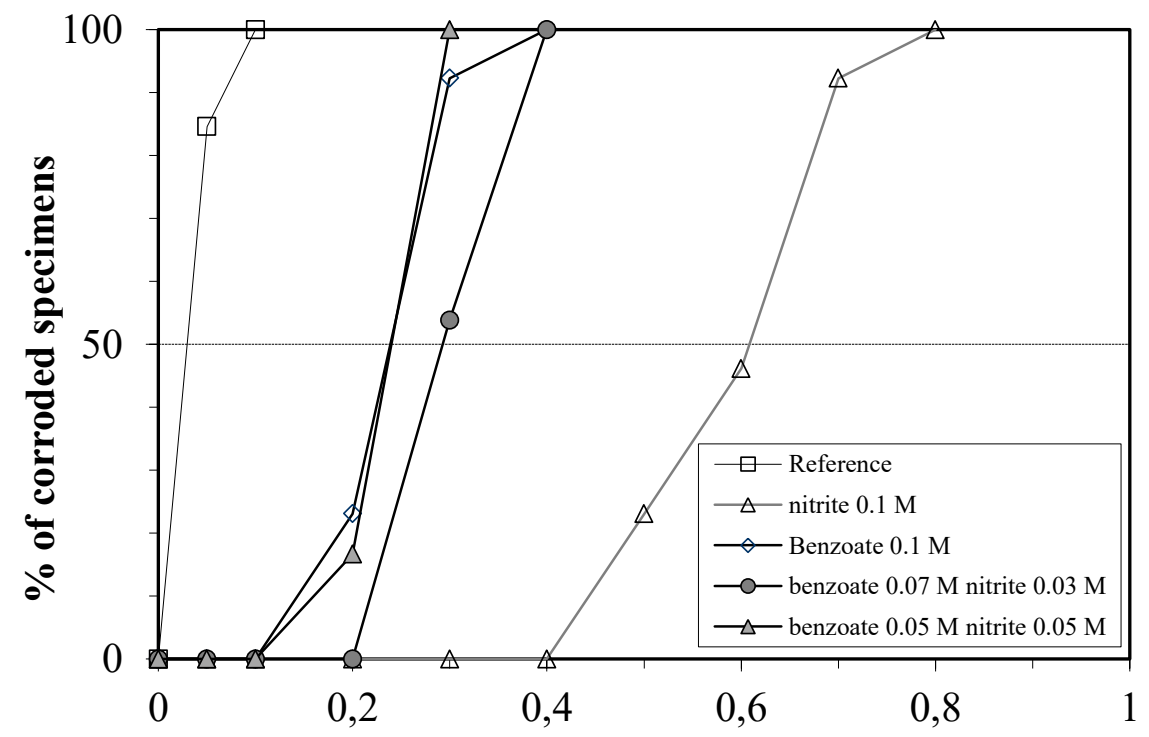

Chlorides $(\mathrm{mol} / \mathrm{L})$

Figure 6. Results of the potentiostatic polarisation tests: effect of nitrite-benzoate concentration. 


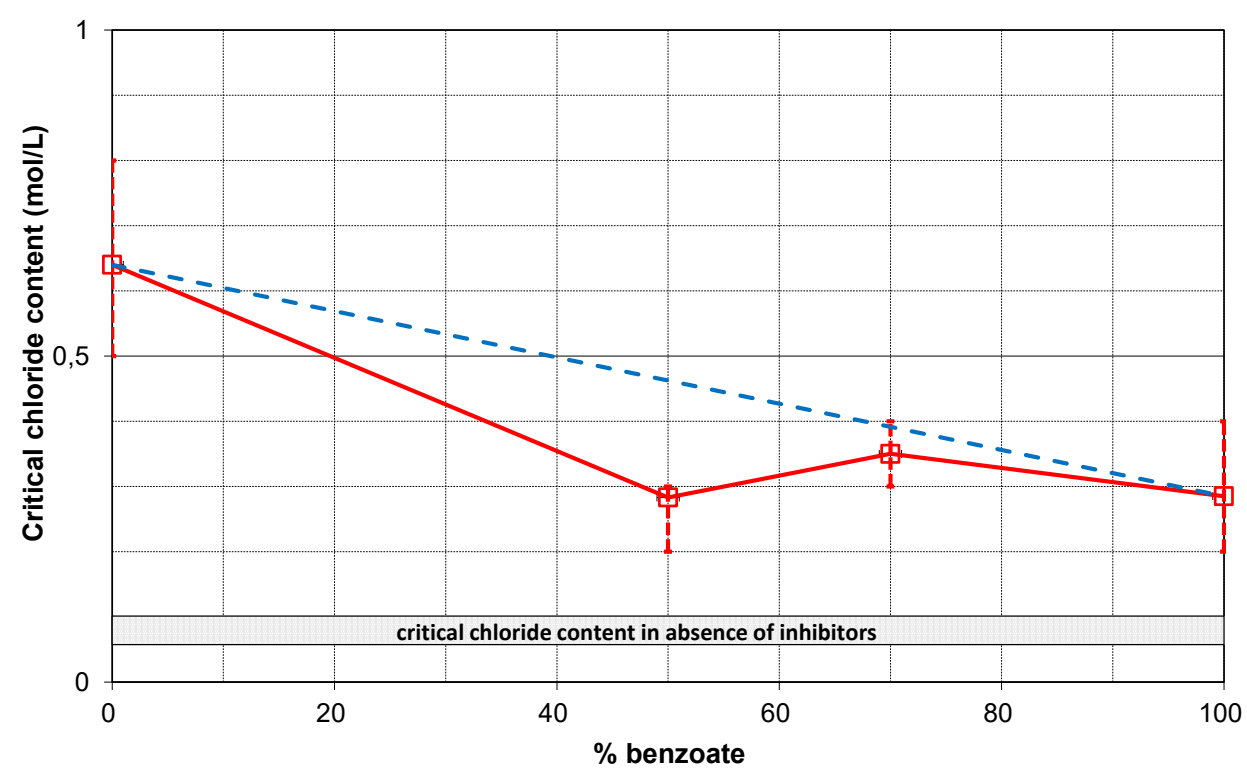

Figure 7. Effect on critical chloride content measured in potentiostatic polarization tests for nitrite-benzoate mixtures.

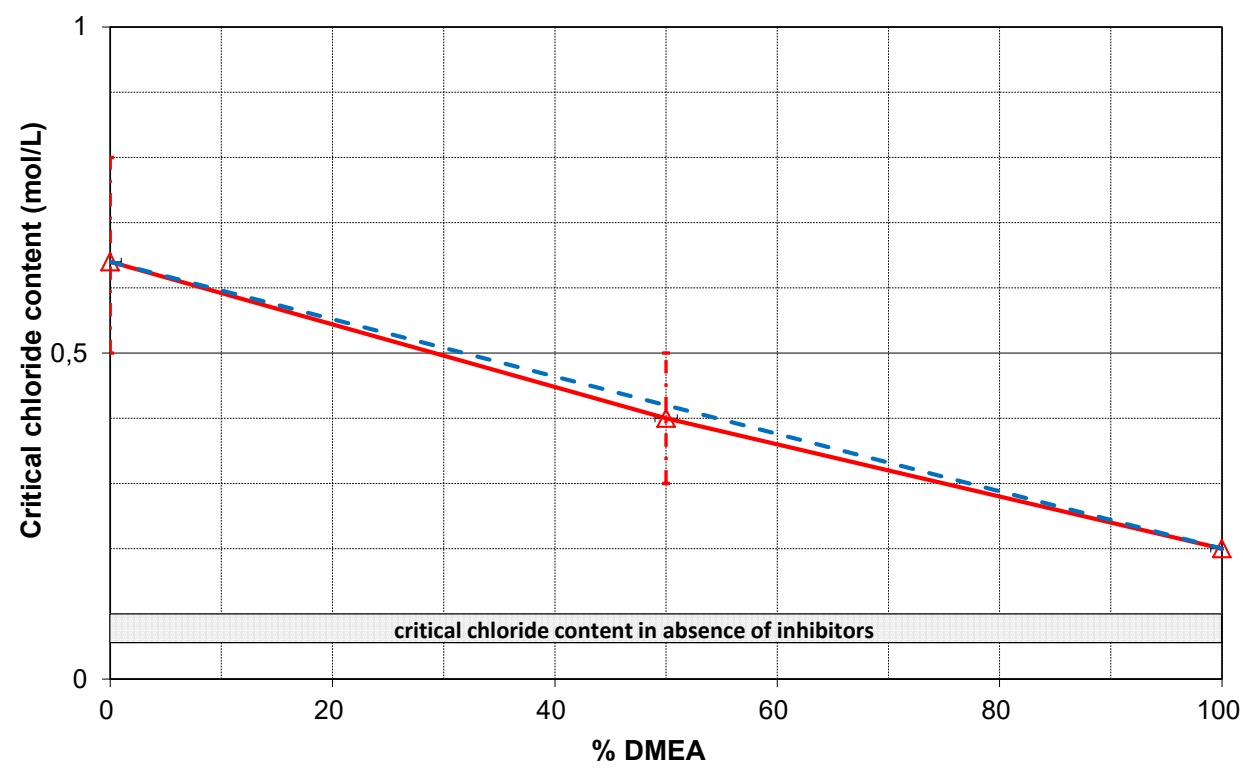

Figure 8. Effect on critical chloride content measured in potentiostatic polarization tests for nitrite-DMEA mixtures. 


\section{Conclusions}

This essay sets out the results of electrochemical tests (potentiodynamic and potentiostatic polarization) carried out on binary mixtures obtained by combining 2 organic substances and sodium nitrite. The tests, carried out in alkaline solution containing $0.1 \mathrm{~mol} / \mathrm{L}$ of chlorides, and with total concentration of inhibitors $0.1 \mathrm{~mol} / \mathrm{L}$, made it possible to determine, for of each mixture, the pitting potential and the critical chloride concentration and accordingly study any synergistic effects.

The mixture that have yielded the best results in potentiodynamic polarisation results is the benzoate $0.07 \mathrm{~mol} / \mathrm{L}$ - nitrite $0.03 \mathrm{~mol} / \mathrm{L}$, with a significant synergistic effect. Nevertheless, this mixture did not confirm the same trends in potentiostatic polarization tests, in which additive effects were shown for higher benzoate concentration, with even pejorative effects for lower concentration of benzoate.

The mixtures nitrite-DMEA did not show any interesting inhibiting properties in both potentiodynamic and potentiostatic polarization tests, and this result is surely affected by low performances got in all tests carried out with DMEA alone. Also in these mixtures additive behavior prevails.

\section{References}

1. L. Bertolini, B. Elsener, E. Redaelli, P. Pedeferri and R. Polder, Corrosion of steel in concrete: prevention, diagnosis, repair, Wiley, Weinheim, 2013.

2. P. Pedeferri, Constr. Build. Mater., 1996, 10, no. 5, 391.

3. EN 206, Concrete Part 1: specification, performance, production and conformity.

4. EN 1992-1-1, Eurocode 2: design of concrete structures - Part 1-1: general rules and rules for buildings.

5. B. Elsener, Corrosion inhibitors for steel in concrete - State of the art report, EFC Publications, 2001, No. 35.

6. Yu.I. Kuznetsov, Int. J. Corros. Scale Inhib., 2015, 4, no. 1, 15. doi: 10.17675/23056894-2015-4-1-015-034

7. C.L. Page, in: Proceedings of the Ninth European Symposium on Corrosion Inhibitors, 2000, University of Ferrara (Italy), p. 261.

8. S.N. Alekseev, V.B. Ratinov, N.K. Rozental' and N.M. Kashurnikov, Ingibitory korrozii stali $v$ zhelezobetonnykh konstruktsiyakh (Steel corrosion inhibitors in reinforced concrete structures), Moscow, Stroiizdat, 1985 (in Russian).

9. N.S. Berke and T.G. Weil, in "Advances in Concrete Technology", Int. Conf. CANMET, Athen, Greece, 1992, pp. 899-924.

10. C.K. Nmai, S.A. Farrington and G.S. Bobrowsky, Concr. Int., 1992, 14, 45.

11. U. Mader, Concrete, 1999, 9, 215.

12. W. Morris and M. Vazquez, Cem. Concr. Res., 2002, 32, 259.

13. E. Rakanta, T. Zafeiropoulou and G. Batis, Constr. Build. Mater., 2003, 44, 507.

14. F. Wombacher, U. Maeder and B. Marazzani, Cem. Concr. Compos., 2004, 26, 209. 
15. L. Mechmeche, L. Dhouibi, M. Ben Ouezdou, E. Triki and F. Zucchi, Cem. Concr. Compos., 2007, 29, 365.

16. T.A. Soylev and M.G. Richardson, Constr. Build. Mater., 2008, 22, 609.

17. N.N. Andreev, D.S. Bulgakov, I.A. Gedvillo, A.S. Zhmakina and S.S. Vesely, Int. J. Corros. Scale Inhib., 2014, 3, no. 4, 238. doi: 10.17675/2305-6894-2014-3-4-238-245

18. N.N. Andreev, I.A. Gedvillo, A.S. Zhmakina, D.S. Bulgakov and S.S. Vesely, Int. J. Corros. Scale Inhib., 2016, 5, no. 4, 319. doi: 10.17675/2305-6894-2016-5-4-2

19. C. Monticelli, A. Frignani and G. Trabanelli, Cem. Concr. Res., 2000, 30, 635.

20. N.N. Andreev and O.A. Goncharova, Prot. Met., 2004, 40, no. 3, 257 (Transl. from Zashch. Met., 2004, 40, no. 3, 280).

21. E.V. Starovoitova, I.A. Gedvillo, A.S. Zhmakina and N.N. Andreev, Prot. Met. Phys. Chem. Surf., 2010, 46, no. 7, 793.

22. C. Monticelli, A. Frignani, A. Balbo and F. Zucchi, Mater. Corros., 2011, 62, 178.

23. T. Pastore, M. Cabrini, L. Coppola, S. Lorenzi, P. Marcassoli and A. Buoso, Mater. Corros., 2011, 62, no. 2, 187.

24. S.-H. Tae, Constr. Build. Mater., 2012, 35, 270.

25. M. Cabrini, S. Lorenzi and T. Pastore, Electrochim. Acta, 2014, 124, 156.

26. F.L. Fei, J. Hu, J.X. Wei, Q. Yu and Z. Chen, Constr. Build. Mater., 2014, 70, 45.

27. J.O. Okeniyi, O.A. Omotosho, O.O. Ajayi and C.A. Loto, Constr. Build. Mater., 2014, 50, 448.

28. H.S. Ryu, J.K. Singh, H.M. Yang, H.S. Lee and M.A. Ismail, Constr. Build. Mater., 2016, 114, 223.

29. W. Martinez, A. Torres, R. Hernández, E. Alonso, I. Mendoza and I. Martinez, AntiCorros. Meth. Mater., 2016, 63, 65.

30. H. Bensabra, N. Azzouz, O. Aaboubi and J.P. Chopart, Metall. Res. Technol., 2016, 113, 102.

31. M. Ormellese, F. Bolzoni, L. Lazzari and P. Pedeferri, Mater. Corros., 2008, 59, 98.

32. M. Ormellese, L. Lazzari, S. Goidanich, G. Fumagalli and A. Brenna, Corros. Sci., 2009, 51, 2959.

33. M. Ormellese, F. Bolzoni, L. Lazzari, A. Brenna and M. Pedeferri, Mater. Corros., 2011, 62, no. 2, 170.

34. F. Bolzoni, A. Brenna, G. Fumagalli, S. Goidanich, L. Lazzari, M. Ormellese and MP. Pedeferri, Int. J. Corros. Scale Inhib., 2014, 3, no. 4, 254. doi: $\underline{10.17675 / 2305-}$ 6894-2014-3-4-254-278

35. ASTM G 61, Standard Test Method for Conducting Cyclic Potentiodynamic Polarization Measurements for Localized Corrosion Susceptibility of Iron-, Nickel-, or Cobalt-Based Alloys. 